.371 .504

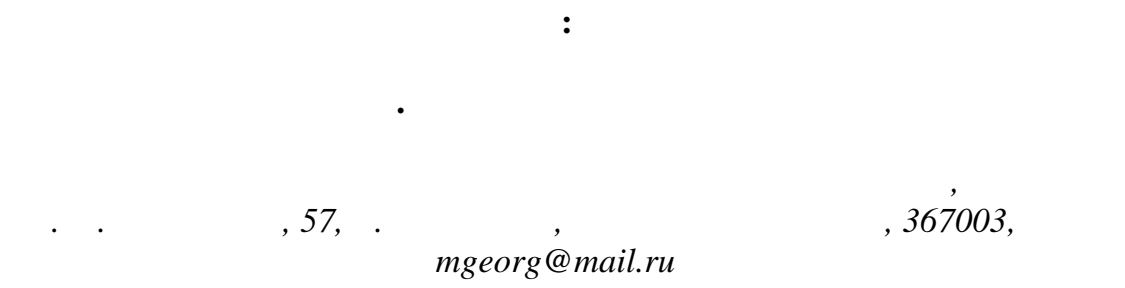

озкрито внесок р дянських і російських учених у 60-90-ті роки ст. у розробку теорії екологічної освіти. ро н лізов но ідеї, погляди й головні концепції системи екологічної освіти школярів, н ведені у пр цях провідних спеці лістів екологічної освіти.

лючові слов : природоохоронн освіт, екологічн освіт, екологічн культур , ст лий (зрівнов жений) розвиток.

о поч тку ХХІ ст. нег тивний вплив суспільств н н вколишне природне середовище сягнув величезних м сшт бів, що призвело до виникнення пл нет рної екологічної кризи.

умов глоб льної екологічної кризи, що охопил всю пл нету н прикінці -н поч тку ст. особливої кту льності н був є екологічн освіт всіх гром дян пл нети ( не лише молоді).

кологічн освіт - це безперервний спеці льно орг нізов ний процес н вч ння, вихов ння т розвитку учня, спрямов ний н формув ння системних н укових і пр ктичних природоохоронних т екологічних зн нь про довкілля, умінь і н виків екологічної діяльності й формув ння основ екологічної культури в контексті концепції ст лого розвитку [5].

к с мостійн г лузь пед гогічного зн ння, екологічн освіт у другій половині

ст. отрим л визн ння в усьому світі.

ля припинення і пом'якшення впливу пл нет рної екологічної кризи, що зрост $є, \epsilon$ лише кільк головних шляхів:

- військовий (н йефективніший) - 3 пров дження тимч сового військового контролю міжн родних орг ніз цій н д кр їн ми і регіон ми, де н ціон льним уряд м не вд ється протистояти екологічній к т строфі ( т ін.), тобто для ліквід ції з грози усьому людству необхідне введення тимч сової зовнішньої військової дміністр ції міжн родних орг ніз цій, що зумовлене потребою вжиття низки н дзвич йних 3 ходів - політичних, економічних т інших, які повинні бути спрямов ні н припинення дії головних компонентів екологічної кризи (які вплив ють н всю пл нету) т пом'якшення особливо небезпечних iï н слідків;

- політичний - вжиття уряд ми ( в особливих вип дк х, і н вимогу міжн родних орг ніз цій) к рдин льних з ходів політичного й економічного х р ктеру, метою яких $є$ перехід н екологічно орієнтов ну економіку;

(C) едюрм гомедов ., 2010 
- освітній - створення ефективної системи екологічної освіти, головною метою якої $€$ формув ння екологічної культури суспільств й особистості.

сі н зв ні шляхи можн успішно ре лізув ти з умови широком сшт бної підтримки з боку з собів м сової інформ ції. йнебезпечнішим для людств $є$ перший шлях, що може м ти непередб чув ні н слідки (можливість перерост ння у трив ле протистояння різних соці льних сил). и вв ж ємо, що сьогодні лише в окремих регіон х пл нети ще можн ефективно ре лізув ти н пр ктиці другий і третій шляхи.

йбільший інтерес для н с м є третій шлях. ітчизняні вчені розгляд ють екологічну освіту як один із з собів пом'якшення екологічної кризи. в ж ють, що освіт , будучи цілеспрямов ною прогр мою соці ліз ції людини, як з безпечує їй ніби друге н родження і робить їі людиною повною мірою, повинн ст ти ефективним мех нізмом ст новлення екологічної культури.

ит ння освіти, які відобр ж ють особливості вз ємодії суспільств з природним середовищем, з вжди посід ли в жливе місце в пед гогічних погляд х т ких учених, як . оменський, . окк, .- . уссо, . ест лоцці, . істервег, . шинський, т інших просвітителів, які з клик ли н вч тися від природи зовнішньої і внутрішньої т відповідно до неї виховув ти дитину. скільки ж вплив людини і суспільств н природу в цей період не був т ким м сшт бним, то мету формув ння відповід льного ст влення до неї не було.

поч тку ст. (1913) з'явився термін “охорон природи”. ін н був зн чного поширення після іжн родного з'їзду з охорони природи, який відбувся того ж року. оді головною формою охорони природи було створення з повідників, мет яких охорон природних п м'яток. отім, з ускл дненням вз ємозв’язків людини з середовищем, змінився і зміст поняття “охорон природи”. оч ли усвідомлюв ти ідею про необхідність готув ти молоде покоління до охорони природи. к 3 поч тков но природоохоронне вихов ння учнів - прообр з м йбутньої екологічної освіти школярів. утність природоохоронного вихов ння розуміли як цілеспрямов не формув ння в учнів н укових поглядів н розвиток і функціонув ння природи т їі ресурсів, необхідну умову життя суспільств , з кл д ння умінь пр вильно поводитись у природі, p ціон льно ст витися до іiі ресурсів у м йбутній пр ктичній діяльності.

г торічн діяльність освітніх уст нов з охорони природи не м л серйозної теоретичної концепції і грунтув л сь перев жно н емпіричному досвіді окремих учених і вчителів-ентузі стів. же в середині 50-х років ст. проблем охорони природи потребув л н укового обгрунтув ння природоохоронної діяльності.

чені у 50-60-х рок х ст. поч ли розробляти проблеми природоохоронної (екологічної) освіти як окремого н укового н пряму і як г лузі н укової пед гогіки. . вєрєв, . хлєбний, . ур вєгін т інші в теоретичних пр цях обгрунтув ли (опир ючись н досягнення пед гогічної н уки того ч су) цілі, визн чили з вд ння природоохоронної освіти, з пропонув ли н уково обгрунтов ні з соби і методи вирішення цих 3 вд нь.

цей період перед вітчизняною школою пост ло нове $з$ вд ння - вихов ння в учнів відповід льного ст влення до природи. озробк теоретичних проблем природоохоронної освіти, уточнення цілей і розширення з вд нь пед гогічної діяльності середніх з г льноосвітніх уст нов ст ло однією з причин поступової відмови від використ ння термін "природоохоронн освіт " і поширення термін “екологічн освіт".

ермін “екологічн освіт” з пров джено 1970 р. н конференції в рсон- іті ( , ев д ): екологічн освіт - це процес усвідомлення людиною цінності н вко- 
лишнього середовищ й уточнення головних положень, необхідних для отрим ння зн нь т умінь для розуміння й визн ння вз ємоз лежності між людиною, ії культурою т біофізичним оточенням. кологічн освіт т кож охоплює н буття пр ктичних н виків у вирішенні з вд нь, шо стосуються вз ємодії з довкіллям, виробленням поведінки, як сприяє поліпшенню якості довкілля. епер під екологічною освітою розуміють безперервний процес н вч ння, вихов ння і розвитку особистості, спрямов ний н формув ння системи н укових і пр ктичних зн нь, ціннісних орієнт цій, поведінки і діяльності, які з безпечують відповід льне ст влення до н вколишнього соці льно-природного середовищ [5].

пед гогічній теорії н мітил сь стійк тенденція розвитку екологічної освіти в с мостійну ч стину з г льної освіти. 3 ємодію 3 н вколишньою дійсністю розгляд ли як умову і з сіб розвитку учнів.

дним із з вд нь екологічної освіти ст ло формув ння екологічної свідомості учнів. отреб в екологіз ції свідомості зумовлен об'єктивними чинник ми (небезпечною гостротою екологічних суперечностей, ре льністю екологічної кризи, необхідністю 3 побіг ння екологічному кр ху, якісним ст ном н вколишнього природного середовищ ), які відобр ж ють н г льні потреби суспільств . кологіз ція свідомості суспільств й особистості пов'яз н з формув нням певних екологічних орієнт цій, і поляг є у перетворенні екологічних уст новок т орієнтирів, які творять міцний фунд мент екологічного мислення, у підгрунтя діяльнісних уст новок.

кологічн свідомість, що є духовно-пр ктичним чинником з своєння дійсності, суттєво доповнює н укове пізн ння специфічним ст вленням людини до світу природи. кологічну свідомість (з погляду нтропоцентризму) можн визн чити як зн ння про вз ємні зв'язки людини і середовищ, їхню зн чимість для людини і для збереження стійкого б л нсу між ними; розуміння й оцінку особистістю своїх можливостей з використ ння цих зв'язків для з доволення потреб і визн чення меж допустимого нтропогенного впливу.

уч сн “індивіду льн” екологічн свідомість учня з лежить від особливостей суспільних стосунків, соці льних уст новок. е д є змогу розгляд ти екологічну свідомість учня як відобр ження в його свідомості процесів вз ємодії між ним (тобто учнем) як особистістю, з одного боку, і суспільством т довкіллям, - 3 іншого, у тих спект х біологічного і соці льного життя, що зумовлені природними чинник ми. ожн вв ж ти, що екологічн свідомість - це систем сформов них і тих, що формуються, когнітивних, етичних, естетичних, пр гм тичних стосунків учня з природою і з с мим собою.

пр ктиці зміст екологічної освіти розкрив ється через систему біо- й екологічних зн нь. ед гоги зрозуміли, шо пост влене 3 вд ння можн вирішити лише 3 соб ми всіх видів природничої і гум ніт рної освіти учнів. роте розуміння екологічної освіти учнів як в жливої с мостійної ч стини з г льної середньої освіти суперечило вимозі розгляду екологічної освіти як невід'ємної ч стини всього н вч льного процесу н всіх ет п х н вч ння.

1980-х рок х різні теоретико-методологічні спекти екологічної освіти досліджув ли . вєтков , . ухомлинський, . оресл вський, . енисов т ін.

. вєтков тр ктув л екологічне вихов ння як дин мічний цілісний процес, який м є суттєві особливості й певні з кономірності [11].

етою екологічної освіти у 1950-1970-ті роки учені вв ж ли формув ння основ екологічної культури учнів шляхом перед в ння зн нь про н укові основи природоко 
ристув ння, необхідність діяти відповідно до них, т кож формув ння в учнів пр ктичних умінь і н виків т ктивної життєвої позиції в сфері охорони природи і р ціон льного використ ння природних ресурсів.

идельковський висловив положення про формув ння особистості з соб ми природи поряд із вл сне соці льними і пед гогічними спект ми [8]. жливим спектом вз ємодії учнів з природою є усвідомлення ними впливів н їхні особисті риси. е сприяє формув нню б ж ння використовув ти явищ природи як 3 сіб с моосвіти і с морозвитку. ерез різном нітну діяльність і орг ніз цію спілкув ння учнів із з лученням явищ природи й учителів вплив ють н формув ння їхньої внутрішньої позиції.

. оресл вський розгляд в ктивно-діяльнісний х р ктер екологічної освіти і сх p ктеризув в його як провідний з сіб формув ння особистості. о головних з вд нь екологічного вихов ння учнів він з числяв вихов ння бережливого ст влення до природи, формув ння в учнів понять про кр су ст влення людей до природи, вихов ння культурних потреб і н виків культурної поведінки у природі т ін.

оль мистецтв в екологічній освіті й вихов нні досліджув ли . ртеменко, . $є$ чко, . мольянінов т ін. і вчені вв ж ли, що різні види мистецтв вплив ють н формув ння різних рис особистості, які сприяють ктивній уч сті учнів в охороні природи і відобр ж ють мор льно-естетичний бік ст влення особистості до природи т іï вплив н особистість [10]. . єчко зі спів втор ми вв ж ли, що розуміння цінності природи як джерел м тері льних і духовних сил суспільств, розвиток необхідності спілкув ння $з$ природою визн ч є м йбутні вз ємовідносини суспільств і людини з н вколишнім природним середовищем [7].

. єчко з пропонув л новий підхід до екологічної освіти і вихов ння: вироблення естетичного ст влення до природи повинно сприяти формув нню в дітей естетичного сприйняття, оцінок і суджень, см ку й іде лу, що передб ч є розвиток чутливості до кр си і вир зності об'єктивних природних явищ, т кож розуміння цінності, унік льності кожного з них [7].

. мольянінов у пр цях з методики викл д ння н ук про природу з зн ч л про необхідність зв'язків н вч льного м тері лу, який вивч ють, з естетичним і екологічним вихов нням. прийняття природи й опосередков не естетичне ст влення до неї 3 допомогою мистецтв повинно формув ти в учнів почуття прекр сного.

роблеми теорії екологічної освіти відобр жені й у пр цях . ухомлинського. ед гог уперше спробув в створити систему екологічної освіти учнів, як $б$ комплексно охоплюв л н вч льну (н буття зн нь про природу, вмінь і н виків з їі охорони) і виробничу діяльність, формув ння гум нної, високомор льної і різнобічно розвинутої особистості. лючов ідея його системи - вихов ння учня через природу. ін ув ж в природу в жливим джерелом думки і розвитку розумових здібностей учня. пілкув ння 3 природою повинно м ти х р ктер творчої діяльності й бути проникнуте співчуттям до всього живого. ід ч с спілкув ння з природою в учнів 3 допомогою емоцій розвив ються бл городні, високі почуття. истем екологічної освіти . ухомлинського спрямов н н формув ння г рмонійних вз ємовідносин між природою т учнем.

еорія і пр ктик екологічної освіти н бул суттєвого розвитку у дослідженнях . вєрєв . кологічну освіту він розумів як процес н вч ння, вихов ння і розвитку особистості, спрямов ний н формув ння системи н укових і пр ктичних зн нь, ціннісних орієнт цій, поведінки і діяльності, що з безпечують відповід льне ст влення до н вколишнього соці льно-природного середовищ . етою екологічної освіти він ув ж в формув ння відповід льного ст влення учнів до довкілля: 
- відповід льність 3 збереження природи, як визн ч є умови життя особистості, з якими вон пов'яз н і н які діє у процесі життєдіяльності;

- відповід льність з здоров'я (своє й інших людей) як особистісну й гром дську цінність;

- екологічну і природоохоронну діяльність, проп г нду ідей оптиміз ції вз ємодії суспільств і природи, попередження нег тивних н слідків впливу н н вколишнє середовище людини т її здоров'я [2].

еобхідним рівнем сформов ності в учнів відповід льного ст влення до н вколишнього природного середовищ . вєрєв ув ж в ре льний внесок кожного учня в поліпшення довкілля. ля успішного формув ння в учнів екологічної відповід льності . вєрєв з пропонув в т ку систему вз ємопов'яз них пед гогічних з вд нь:

- н вч ння (формув ння зн нь про єдність живої і неживої природи, розкриття з кономірностей природних явищ, вз ємодії природи, суспільств і людини; зн ння екологічних проблем і способів їх вирішення; системи теоретичних і пр ктичних умінь 3 вивчення і поліпшення ст ну н вколишнього природного середовищ );

- вихов ння (вироблення ціннісних орієнт цій екологічного х р ктеру, мотивів і потреб, звичок екологічно доцільної поведінки й діяльності, волі, н полегливості у досягненні екологічних цілей);

- розвиток (здібності до н лізу екологічних проблем і вибору оптим льних способів їхнього вирішення; екологічного мислення; перекон нь у необхідності і можливості вирішення екологічних проблем; пр гнення особистої уч сті в пр ктичній екологічній діяльності).

. вєрєв з зн ч в, що екологічну культуру можн сформув ти лише безперервним підвищенням рівня з г льної культури суспільств і людини. ля цього він пропонув в міжпредметний підхід, який передб ч є узгодження змісту і методів розкриття з конів, принципів і способів оптим льної вз ємодії суспільств з природою н всіх рівнях екологічних зн нь, з кл дених у н вч льних предмет х. кологічн освіт у пр цях . вєрєв спрямов н н формув ння культури ст влення учнів до природи.

еоретичні основи екологічної освіти школярів н йповніше розробил ур вєгін . основі теорії екологічної освіти - т кі концепту льні положення:

- ідея єдності системи природ -суспільство-людин ;

- людство - скл дов природи (його розвиток - нег тивний чинник дегр д ції природи);

- історія людств - ч стин історії “дегр д ції природи” (перетворення природи сьогодні є н йбільшою небезпекою для життя);

- єдність історії природи й історії суспільств ;

- екологічн культур особистості й суспільств (новий рівень відносин у системі людин -природ ).

. ур вєгін вв ж є ефективним н прямом удоскон люв ння екологічної освіти учнів у школі екологіз цію змісту шкільної освіти (як містить систему зн нь про вз ємодію суспільств і природи, ціннісні екологічні орієнт ції, систему вмінь і н виків з їі вивчення й охорони, норми і пр вил ст влення до природи), з своєння учнями н йв жливіших теоретичних понять і світоглядних ідей екологічного змісту [9]. ормув ння екологічної культури, у підгрунті якої, н її думку, є н уковий світогляд, повинно бути ч стиною освітнього процесу, пок зник її сформов ності - екологічн діяльність учнів. 
ктивно опр цьовув в теорію екологічної освіти . хлєбний [1]. озгляд ючи вз ємовідносини у системі суспільство-природ , він з'ясув в т кі їхні особливості:

- розвиток промисловості н пл неті призводить до порушення цілісності біосфери;

- розвиток промисловості призводить до з бруднення речовин ми, які не були скл довими природного кругообігу біосфери (це, відповідно, призводить до іï поступового руйнув ння);

- зникнення природних ресурсів породжує нові проблеми (пошук і використ ння нових джерел енергії т сировини, що призводить до нових екологічних проблем).

. хлєбний особливу ув гу в теорії екологічної освіти відвів вирішенню проблем розроблення системи з вд нь, спрямов них н розвиток ціннісних орієнт цій школярів, формув ння потреби в природоохоронній т екологічній діяльності. блоки:

еоретичн модель екологічної освіти (розроблен . хлєбним) містить чотири

- перший блок об’єднує чинники, що визн ч ють формув ння світогляду, погляди, перекон ння і вчинки учнів;

- другий блок - це чинники, які визн ч ють вл стивості особистості учня в конкретних вид х діяльності (поведінки);

- третій блок об'єднує пед гогічні умови впливу н особистість учня (почуття, інтелект тощо);

- четвертий блок містить пед гогічні з соби, з допомогою яких з безпечують екологічну освіту учнів.

зміст екологічної освіти учнів . хлєбний увів:

- систему зн нь про природу, суспільство, принципи природокористув ння, про шляхи оптиміз ції вз ємодії у системі суспільство-природ );

- систему н виків т умінь (інтелекту льних і пр ктичних) екологічно-орієнтов ної діяльності;

- досвід діяльності з вивчення і ре льної пр ктичної уч сті в охороні природи;

- систему норм, які з'являються в оцінно-емоційному ст вленні до природи.

истему екологічних зн нь . хлєбний пов'язув в із системою природничон укових, гум ніт рних т інших термінів, які відповід ють шкільним дисциплін м. тже, . хлєбний розгляд в екологічні проблеми у н вч льному процесі як вз ємодію природи і суспільств .

поч тку 90-х років ст. в “екологічній пед гогіці” н зріл необхідність у системному підході до дослідження проблем екологічної освіти учнів. е було зумовлене потребою перебороти:

по-перше, відмінності суч сних н укових зн нь, н копичених у пед гогіці, психології, екології т ін.;

по-друге, розрізненість еколого-виховного впливу школи й інших соці льних інституцій, у тім числі й з собів м сової інформ ції, н особистість учнів;

по-третє, відмінностями у вимог х, які ст вили пед гоги до учнів під ч с освітнього процесу.

озробкою екологічної освіти школярів н підст ві ідеї системного підходу у цей періодз йм лися . роп, . іх чьов, . учер т ін.

. роп , розробляючи чотирирівневу модель екологічної освіти, висунув т кі теоретичні положення [3]: 
- екологічн освіт учнів - це кту льн міждисциплін рн проблем (соці льноекономічн і психолого-пед гогічн ), суттю якої є формув ння в учнів відповід льного ст влення до природи, і для вирішення якої потрібен системний підхід;

- екологічн освіт учнів - це цілеспрямов ний процес формув ння системи н укових зн нь, поглядів і перекон нь, умінь і н виків, ціннісних орієнт цій, мор льних якостей, які зумовлюють вироблення в учнів ст влення до природи як до універс льної цінності;

- мор льною якістю особистості учня є екологічн відповід льність (у підгрунті якої є певний рівень розвитку мотив ційно-ціннісного, змістовно-опер ційного (процесу льного) і оцінно-результ тивного компонентів);

- екологічн освіт учнів повинн бути спрямов н н формув ння їхнього відповід льного ст влення до природи (необхідно поєдн ти н вч ння, поз кл сну роботу, екологічну діяльність учня);

- пед гогічними умов ми ефективної екологічної освіти учнів є: використ ння системного підходу в екологічній освіті; ур хув ння специфіки ст влення учнів до природи; внесення до змісту шкільної освіти природничих і гум ніт рних зн нь про суперечності в системі суспільство-природ ; вз ємозв'язки етичного й екологічного вихов ння; з лучення учнів до різних видів природоохоронної й екологічної діяльності.

підст ві перелічених теоретичних положень . роп з пропонув в т ку чотирирівневу модель екологічної освіти учнів:

- перший рівень містить компоненти: людин , суспільство, виробництво, природ ;

- другий рівень формують соці льні інститути (сім'я, підприємство, гром дськість, з соби м сової інформ ції);

- третій рівень - освітній з кл д, який з безпечує цілеспрямов ну екологічну освіту учнів і координує еколого-виховні впливи н них з боку інших соці льних уст нов держ ви;

- четвертий рівень - особистість учня (систем екологічної освіти спрямов н н формув ння у нього відповід льного ст влення до природи).

инішня екологічн ситу ція зумовлює нові к нони рівня культури й освіченості, які повинні ст ти орієнтир ми для розроблення ефективної теорії екологічної освіти учнів освітніх з кл дів. суч сних умов х формув ння і розвиток екологічної культури особистості спонук ло до переорієнтув ння системи шкільної освіти н нову екогум ніт рну п р дигму, як передб ч є пріоритетність екологічного зн ння як соціоприродного компонент середньої освіти.

екогум ніт рну п р дигму орієнтов н “ ціон льн стр тегія екологічної освіти в осійській едер ції”, у якій розвинул ся низк проблемних спектів теорії екологічної освіти. цій стр тегії визн чено й теоретично обгрунтов но головні рівні й н прями суч сної екологічної освіти і формув ння н цьому підгрунті екологічної культури особистості. озвиток екологічної культури учнів покл дено н систему середньої екологічної освіти, як є ч стиною системи безперервної освіти, що формується [4].

червні 1992 р. н “ онференції з н вколишнього середовищ і розвитку” в iо-де- нейро визн но концепцію ст лого розвитку людств (в інтерпрет ції російських учених концепція коеволюції, ноосфер , ноосферогенез є норм тивним прогнозом м йбутнього людств ), головні положення якої викл дено в документі “ л н дій н століття" («Agenda 21»). перше людство пост вило з вд ння скоригув ти господ рську діяльність з ур хув нням інтересів м йбутніх поколінь - збереження для них природних ресурсів і сприятливого клім ту н емлі. 
дн к н тлі глибокої економічної кризи зі стрімкою інфляцією, як трив є у , перерозподілу вл сності, вперше пост лим безробіттям, створенням “псевдодемокр тичної держ ви”, ідею ст лого розвитку н селення кр їни не сприйм є серйозно.

т інших кр їн х світу ідею ст лого розвитку критикув ли, оскільки її зміст спрямов но н підтримку цілей глоб ліз ції, і ре льно з вд ння переходу всієї людської цивіліз ції н нові стосунки з природою не пост влене: iї мет - оздоровлення природного середовищ ф ктично лише території кр їн “золотого мільярд ". езв ж ючи н низку 3 ходів щодо попередження глоб льної екологічної кризи, вжитиих н різних рівнях, ст новище не лише не поліпшується, й ст є щор з з грозливішим. е визн в і енеp льний секрет $\mathrm{p}$ офі нн н у доповіді про викон ння прийнятої н конференції в іо-де- нейро прогр ми, з зн чивши, що з минуле десятиліття спроби людств сприяти розвитку і спинити дегр д цію н вколишнього середовищ були м лоефективними і з г лом з зн ли пор зки [6]. дн к пл нет рн екологічн криз , в яку вступило людство н прикінці ст., глоб льні екологічні й інші породжені ними супутні проблеми, які потребують вирішення, сприяють под льшій розробці головних положень “концепції ст лого розвитку” цивіліз ції.

підст ві створених спеці ліст ми різних кр їн світу концепцій ст лого розвитку 3 пропонов но формулу ст лого розвитку: ст лий розвиток людств - це керов ний, прогр мов ний розвиток, що грунтується н вищих досягненнях н уки, технології і культури, відбув ється 3 умов г рмонійної вз ємодії біосфери і людств , м є індекс ст лості розвитку менший від одиниці, спрямов ний н вдоскон лення людини, іiі творчих і духовних н ч л, формув ння творчої особистості, безсмертя людського розуму.

т лий розвиток - це модель розвитку глоб льної екосистеми - біосфери, з якого зберіг ється дин мічн рівнов г між її окремими підсистем ми. $\quad$ р зі переходу цивіліз ції до ст лого розвитку ст влять з вд ння інтегрув ти пит ння ст лого розвитку в системи освіти н всіх рівнях, щоб підтримув ти освіту як ключовий чинник змін [5].

глоб лістиці широко відом ідея едук ціоцентризму, згідно з якою, освіт зд тн розпоч ти комплекс необхідних економічних, політичних т соціокультурних зрушень, які підсумку д ють змогу зменшити небезпечні екологічні суперечності суч сної цивіліз ції. “тр тегії вропейської економічної комісії для освіти в інтерес х ст лого розвитку” (2005) з зн чено, що “освіт є однією з передумов для досягнення ст лого розвитку й озброєння інструментом ефективного упр вління...”. е передб чє не лише озн йомлення учнів з головними положеннями і принцип ми ст лого розвитку (освіт про ст лий розвиток), й зміну стилю життя відповідно до цих принципів (освіт для ст лого розвитку), т кож теоретичну і пр ктичну підготовку до діяльності в г лузі упр вління довкіллям і ст лого розвитку.

деї ст лого розвитку впров джують в освітню г лузь. освітньому контексті ці ідеї орієнтують середню школу н орг ніз цію процесу н вч ння з усвідомлення перспективних н прямів ідеології освіти для ст лого розвитку, що об'єднує екологічну, економічну і культурологічну скл дові цього б г то спектного пит ння. іль екологічної освіти (у контексті ідей ст лого розвитку) - освоєння т ких зн нь, умінь і цінностей, які д дуть змогу молодим поколінням прийм ти індивіду льні й колективні рішення лок льного і глоб льного х р ктеру для поліпшення якості життя без з грози для м йбутнього пл нети.

чевидно, що перехід осії до ст лого розвитку неможливий без створення відповідної системи вихов ння і н вч ння, оскільки мор льність, світогляд, культур м йбутніх поколінь зумовлені систем ми форм льного й неформ льного н вч ння, вихов ння 
i розвитку. $\quad$ л льн освіт $\epsilon$ н йв жливішою з-поміж передумов ст лого розвитку системи людин -суспільство-біосфер .

суч сній російській з г льній т екологічній освіті поширився компетентнісний підхід. чені стверджують, що:

- компетентнісний підхід виявляється як оновлення змісту освіти у відповідь н мінливу соці льно-економічну ре льність ( . румін);

- компетентність м є можливість перенесення зд тності в умови, відмінні від тих, у яких ця компетентність виникл ( . шев);

- компетентність визн ч ють як "готовність долучитися до певної діяльності" ( . ронов) чи як трибут підготовки до м йбутньої діяльності ( . едровицкий) тощо.

и вв ж ємо, що компетентнісний підхід безпосередньо пов’яз ний з ідеєю цілеспрямов ності т цільовості освітнього процесу, з якого компетенції ст влять вищий, уз г льнений рівень умінь і н виків учня, зміст екологічної освіти визн чений чотирикомпонентною моделлю змісту освіти (зн ння, уміння, досвід творчої діяльності і досвід ціннісного ст влення).

зн чимо, що екологічн компетенція є результ том формув ння і розвитку в молоді екологічної культури. кологічн компетентність учня - це інтегр тивн рис особистості, як визн ч є їі зд тність вз ємодіяти в системі людин -суспільство-природ відповідно до з своєних екологічних зн нь, умінь, н виків 3 перекон нням, мотив ми, ціннісними уявленнями, екологічно зн чимими особистісними рис ми і пр ктичним досвідом екологічної діяльності.

кологічн компетентність учня охоплює когнітивний, мотив ційно-ціннісний і діяльнісно-пр ктичний компоненти:

- когнітивний компонент передб ч є сформов ність системи екологічних зн нь (природничих, світоглядних, норм тивно-пр вових, пр ктичних), які визн ч ють спосіб природоохоронної й екологічної діяльності;

- мотив ціно-ціннісний компонент - це уст лен систем мотив ціно-ціннісних освіт (інтересів, потреб, перекон нь, ціннісних уявлень); соці льно в гомих мотивів (гром дянських, гум ністичних, естетичних), екологічно в гомих особистісних рис (гум нність, емп тність, бережливість, відповід льність);

- діяльнісно-пр ктичний компонент з безпечує сформов ність екологічних умінь т н виків, викон ння норм і пр вил поведінки у природі, пр ктичного досвіду екологічної діяльності.

роте, як з свідчує досвід шкільних учителів (зокрем , івденного федер льного округу ), впров дження компетентнісного підходу в екологічну освіту не було успішним - рівень екологічної культури учнів (зокрем , ії діяльнісного компонент ) невисокий. одноч с ця робот д л змогу н копичити певний досвід, зробити деякі висновки (компетентнісний підхід є зусиллям прикл дного х р ктеру середньої екологічної освіти) і сформулюв ти рекоменд ції для под льших досліджень.

p зі нем єдиної чіткої теорії екологічної освіти, і перехід н «екоосвіту» не відбувся. дн к уже сьогодні зрозуміло, що переорієнтув ння систем освіти н впров дження концепцій “ст лого розвитку” і “коеволюції природи і суспільств ”, ксіології й мор лі невідворотне.

основі суч сної теорії екологічної освіти є уявлення про коеволюцію природи і суспільств оісеєв , які передб ч ють включення життєдіяльності людини у ст більні біогеохімічні цикли. теорії екологічної освіти можн виділити дв рівні: 
1) стр тегічний, спрямов ний н перекон ння про необхідність зміни п р дигми існув ння людств , н прищеплення розуміння того, що перехід до нових цивіліз ційних основ з лежить не лише від урядів і різних міжн родних орг ніз цій, й від кожної окремої людини;

2) т ктичний, пов'яз ний з освітою гром дян, зд тних вчиняти дії, спрямов ні н перехід до ресурсо- і енергозбереження, до високої екологічної культури.

н ліз теорії і пр ктики середньої екологічної освіти д є змогу виділити різні групи моделей, пробов ні і дост тньо теоретично обгрунтов ні, які ре лізують в освітніх уст нов $\mathrm{x}$ :

1) однопредметн модель передб ч є вивчення екології як с мостійного предмет (цей підхід рекомендов ний сесвітньою х ртією охорони природи, де з зн чено, що “курси охорони довкілля" повинні ст ти скл довою з г льної системи освіти);

2) б г топредметн модель передб ч є глибоку екологіз цію змісту в логіці побудови тр диційних н вч льних предметів;

3) зміш н модель об'єднує екологізов ний зміст тр диційних н вч льних предметів і с мостійні інтегров ні предмети.

освід ре ліз ції цих моделей з свідчує, що зміш н модель виявляється н йперспективнішою з огляду н іiі комплексність і цілісність.

ині в теорії екологічної освіти школярів розроблено низку пед гогічних підходів (н підст ві досягнень психології, соціології тощо), які поширилися в різних кр їн х світу, у тому числі й у осії, і які використовують у пр ктиці середньої екологічної освіти. о них н леж ть:

- суб'єкт-об'єктивний підхід (викл д ч - суб'єКт, учень - об'єКт пед гогічної діяльності) передб ч є рівнопр вну вз ємодію учня і викл д ч , без якої вирішення екологічних проблем освітніми з соб ми неможливе;

- інтер ктивний підхід (це н вч ння, з нурене у спілкув ння) - до інтер ктивних методів н вч ння школярів можн з числити, зокрем, спрямов ну дискусію, рольові й іміт ційні ігри, моделюв льні ситу ції - спрямов ні н вирішення соці льно-екологічних проблем;

- холістичний підхід (з снов ний н цілісній єдиній роботі обох півкуль головного мозку). чні з домін нтним лівопівкульовим типом пізн в льної діяльності сильніші в теорії, ніж у пр ктичних діях, т ких в жливих для вирішення екологічних проблем;

- ф льсифік ційний підхід (в освітньому контексті озн ч є створення сприятливих умов) передб ч $є$ створення н $з$ няттях середовищ, оптим льного для вирішення освітнього з вд ння н 3 с д х співпр ці й підтримки учнів, вірі у їхні здібності, сприяють розвитку н виків вироблення вл сної думки, формув нню ктивної життєвої позиції і с море ліз ції учнів.

і підходи повинні ст ти основою нових пед гогічних методик з підвищення ефективності екологічної освіти школярів.

тже, розроблення теорії екологічної освіти учнів у пр цях учених - це пед гогічний цілеспрямов ний процес формув ння системи зн нь, поглядів і перекон нь, умінь і н виків, ціннісних орієнт цій, мор льно-екологічних рис, що зумовлюють формув ння в учнів ст влення до природи як до універс льної цінності.

зн чимо, що цілі й з вд ння екологічної освіти учнів соці льно зумовлені, вони є сукупністю вимог, які ст влять до оптиміз ції відносин у системі людин -суспільствоприрод · оловний зміст екологічної освіти школярів у теорії т н пр ктиці розкрив ють як систему міжпредметних екологічних ідей, природничих т етичних зн нь, еколо- 
гічних, мор льно-екологічних понять, орієнт ції н природу як універс льну цінність і комплекс інтелекту льних і пр ктичних умінь т н виків.

оловними пед гогічними умов ми підвищення ефективності суч сної екологічної освіти учнів учені вв ж ють: ре ліз цію системного підходу в екологічній освіті і вихов нні; ур хув ння специфіки ре льного ст влення учнів до природи; зб г чення учнів природничими і гум ніт рними зн ннями про суперечливу єдність людини і суспільств 3 природою; орг нічний вз ємозв'язок мор льного й екологічного вихов ння; 3 лучення учнів до різних видів еколого-орієнтов ної діяльності; підготовк вчителівпредметників і кл сних керівників до вирішення з вд нь суч сної екологічної освіти школярів.

1. хлебный . . и др. ед гогические принципы и условия экологического обр зов ния: н уч. тр. $\quad . \quad$, 1983.98 с.

2. верев . ., ур вегин . . рг низ ция экологического обр зов ния в школе. ермь: . и., 1990. $148 \mathrm{c}$.

3. pon . . еоретические основы экологического обр зов ния школьников. инск: ц. ин-т обр зов ния, 1999. 188 с.

4. цион льн я стр тегия экологического обр зов ния в оссийской едер ции (проект) // естн. экол. обр зов ния в оссии ( риложение). 2000. № 1. . 1-20.

5. едюрм гомедов . . кологическое обр зов ние ст ршекл ссников в учебной деятельности (н м тери ле естественнон учных дисциплин). х чк л , 2007.26 с.

6. существление овестки дня н XXI век/ окл д енер льного секрет ря . - омиссия по устойчивому р звитию, действующ я в к честве подготовительного комитет семирной встречи н высшем уровне по устойчивому р звитию. 28 янв ря-8 февр ля 2002 г. / URL: http://www.un.org/russian/conferen/wssd/docs/ecn17-02pc2-7.pdf.

7. ечко . . и др. кологическое и эстетическое воспит ние школьников. $\quad . \quad$ ед гогик, 1984. $135 \mathrm{c}$.

8. идельковский . . ритерии, методы и методики изучения и формиров ния отношений школьников к природе. т врополь, 1988.

9. $у р$ вегин . . етодическ я систем экологического обр зов ния // ов. пед гогик . 1988. № 9. С. 31-35.

10. молянинов . . рирод в системе эстетического воспит ния. $\quad . \quad$ росвещение, 1984. 79 с.

11. ветков . . кологическое воспит ние мл дших школьников: еория и методик внеурочной р боты. $\quad$.: ед. об-во оссии, 1999. 176 с.

\title{
THEORY AND PRACTICE OF ENVIRONMENTAL EDUCATION AT THE END OF CENTURY: PROBLEMS OF DEVELOPMENT
}

\author{
G. Nedurmagomedov \\ Daghestan State Pedagogical University, \\ M. Yaragskogo St., 57, Makhachkala, Daghestan, 367003, Russia,mgeorg@mail.ru
}

The article discusses the contribution of the Soviet and Russian scientists in the 60-ies and 90-ies of century into the development of the theory of environmental education. It characterizes ideas, opinions and main concepts in the system of pupils' environmental education presented in the works of leading specialists on environmental education.

Key words: environmental education, ecological education, environmental culture, sustainable development. 


\section{: \\ едюрм гомедов \\ гест нский госуд рственный пед гогический университет,

ул. . $\quad$ гского, 57, г. $\quad$ чк, еспублик гест н, 367003, оссия,
mgeorg@mail.ru

скрыто вкл д советских и российских ученых в 60-90-е годы век в р зр ботку теории экологического обр зов ния. х р ктеризов ны идеи, взгляды и основные концепции системы экологического обр зов ния школьников, предст вленные в р бот х ведущих специ листов экологического обр зов ния.

лючевые слов : природоохр нное обр зов ние, экологическое обр зов ние, экологическ я культур , устойчивое р звитие.

т ття н дійшл до редколегії 06.09.2009

рийнят до друку 20.09.2009 